\title{
Implementation of Standard Operational Procedure (SOP) for Services, Government Policy and Information Technology of Communication on Improving Public Satisfaction of Balai Karantina Pertanian Kelas II Medan
}

\author{
Hetty Evarina Situmorang ${ }^{1}$, Endang Sulistya Rini², Sugiharto Pujangkoro² \\ ${ }^{1,2}$ Master of Management Study Program on Postgraduate School of University of Sumatera Utara
}

Corresponding Author: Hetty Evarina Situmorang

DOI: https://doi.org/10.52403/ijrr.20220152

\begin{abstract}
Public satisfaction with the service performance of government officials is influenced by many factors such as application of Standard Operating Procedures (SOP), government policy, and the application of technology and information systems. Principles of Public service such as transparency, accountability, participation, conditionality, equality of rights and obligations as well as the balance of rights and obligations greatly affect public satisfaction with service systems and procedures. The present study is a survey using an associative quantitative approach aimed at determining the effect of the Standard Operating Procedures (SOP) in services, government policy, and information communication technology on improving public satisfaction of Balai Karantina Pertanian Kelas II Medan. The population included the people who used the service as of 80 people using quarantine services. The sampling method used a total sampling method so that there are 80 samples. The data collection method used a questionnaire. The collected data were then analyzed by using multiple linear regression. The results of the study indicated that Standard Operating Procedures (SOP), Government Policies, and Information and Communication Technology and Community Satisfaction have a positive and significant effect on community satisfaction. Standard Operating Procedure (SOP) partially has a positive and significant effect on community satisfaction. Government policies partially have
\end{abstract}

a positive and significant effect on community satisfaction. Information and Communication Technology partially has a significant effect on community satisfaction. It is suggested to the Kantor Balai Karantina Pertanian Kelas II Medan to further improve the quality of service so that consumer satisfaction in online transactions can be further improved

Keywords: Standard Operating Procedure, Government Policy, Technology Information, and Communication

\section{INTRODUCTION}

Community satisfaction is the main factor that must be considered by public service providers because community satisfaction will determine the success of the government in providing public services. The definition of community satisfaction is often confused with the definition of customer satisfaction, this is only distinguished by who the provider is and what is the motive for providing the service. Service providers in public services are employees of government agencies that carry out public service tasks in accordance with the laws and regulations that have been mandated and recipients of public services are people, communities, government agencies, and the business world, who benefit from the activity of providing public services. 
Hetty Evarina Situmorang et.al. Implementation of standard operational procedure (SOP) for services, government policy and information technology of communication on improving public satisfaction of Balai Karantina Pertanian Kelas II Medan.

Increasing community satisfaction with existing services is expected to be obtained by implementing several things, including the application of Service Standard Operating Procedures (SOPs), which are guidelines that contain standard operating procedures that exist within an organization that is used to ensure that all decisions and actions run effectively, efficiently, consistently and systematically standards. To improve services to service users, the Kantor Balai Karantina Pertanian Kelas II Medan has implemented SOPs for each service activity, stipulations of laws regarding applicable tariffs for each service and the use of information and communication technology.

However, there are also several things that become problems in the use of information communication technology, including the unequal ability of officers in the use of communication information technology which can result in differences in work results both between work units and between officers. The development of infrastructure that is still uneven, especially in reaching remote areas is also a problem in the use of this information technology which can make work slower or reports and information that are no longer real time. Several government policies at the Kantor Balai Karantina Pertanian Kelas II Medan are in the form of fees or rates for Non-Tax State Revenue (PNBP) imposed on people who need services. The fees charged to the community differ from one another according to the type of service received.

The existing policies still have several problems, such as the lack of socialization from the Kantor Balai Karantina Pertanian Kelas II Medan to the public regarding quarantine services which has an impact on the lack of information received by the public regarding quarantine measures and the public also does not clearly understand the service mechanism implemented, budget or tariffs that are often considered inappropriate and payment systems that are often constrained or unavailability of service officers at the agency. These things make people disappointed and cause a sense of lack of trust in government agencies because these government policies are considered detrimental to the service user community so that it can lead to an unfavorable relationship between the community and the performance of government agencies.

Based on the analysis of community satisfaction in the 2018 period, it can be seen a decrease in community satisfaction using quarantine services at Kantor Balai Karantina Pertanian Kelas II Medan. The decrease is seen in the elements of courtesy and friendliness of the officers, certainty of service schedules and environmental comfort, then elements of the reasonableness of service costs and certainty of service costs and elements of speed of service. There is a phenomenon of a decrease in the value of the Community Satisfaction Index on some of these elements in the form of a decrease in the elements of Standard Operating Procedures, Information Communication Technology and elements of Government Policy which fell from the previous year.

\section{Community satisfaction}

Satisfaction is a response to the perceived evaluation of the difference between initial expectations before purchase (or other performance standards) and the actual performance of the product as perceived after using or consuming the product. Satisfaction is the level of one's feelings after comparing the perceived performance (outcome) with his expectations (Kotler, 2014).

Community satisfaction is a response to the previously perceived performance of public organizations. The level of satisfaction is a function of the difference between perceived performance and expectations that people can experience one of three general levels of satisfaction. Community satisfaction with public organizations is very important because of the relationship of public trust. According to Pasolong (2010), "The better the 
Hetty Evarina Situmorang et.al. Implementation of standard operational procedure (SOP) for services, government policy and information technology of communication on improving public satisfaction of Balai Karantina Pertanian Kelas II Medan.

government and the quality of services provided, the higher the public trust (high trust)". Public trust will be higher if the community gets good service and feels satisfied with the service.

\section{Standard Operating Procedures (SOP) Services}

Conceptually, Standard Operating Procedures (SOP) is a concrete form of the application of quality management principles that are applied to an organization. Laksmi \& Budiantoro (2008) suggest that SOPs are documents related to procedures carried out chronologically to complete a job that aims to obtain the most effective work results from workers at the lowest possible cost. SOPs usually consist of the benefits, when it was made or revised, the method of writing the procedure, and is accompanied by a flowchart at the end. Tambunan (2013) argues that SOPs are "Guidelines that contain standard operating procedures that exist within an organization that are used to ensure that every decision, step or action and use of processing facilities carried out by people within an organization has been running effectively, consistently, standards and systematically".

\section{Government policy}

Government policy is a government instrument, not only in the sense of government which only concerns the state apparatus, but also governance that touches on the management of public resources. According to Bridgman in Suharto (2012), that public policy generally contains the notion of "whatever government chooses to do or not to do". That is, public policy is 'whatever the government chooses to do or not to do. In other words, government policy is a set of government actions designed to achieve certain results. Nugroho (2010) formulates the definition of public policy as a decision made by the state, especially the government, as a strategy to realize the goals of the country concerned. Public policy is a strategy to lead society in the early days, enter society in transition, to get to the society that they aspire to.

\section{Information technology}

Sutabri (2014) argues that information technology is a technology used to process data, including processing, obtaining, compiling, storing, manipulating data in various ways to produce quality information, namely relevant, accurate and timely information, which is used for purposes of personal, business, and government and is strategic information for decision making. Rusman (2011) defines information and communication technology (ICT) as a medium or tool in obtaining knowledge from one person to another. Furthermore, the Ministry of Research and Technology states that information and communication technology (ICT) as part of science and technology (IPTEK) is generally all technologies related to the retrieval, collection, processing, storage, dissemination and presentation of information.

In accordance with research conducted by (Sirajuddin, 2014) which analyzes local government policies in basic public services in the social sector, (Dharma, 2013) which analyzes the relationship between price policies, services and supporting facilities on customer satisfaction at PT. Semen Tonasa (Ratna, 2018) which links the influence of office facilities, service quality and standard operating procedures (SOP) on visitor satisfaction levels and (Paongganan, 2014) which analyzes the influence of information technology on quality and user satisfaction in library and archive bodies. Supriatna (2013), the implementation of public services by government officials to the community is closely related to efforts to create community satisfaction as service recipients. This is actually an implication of the function of the state apparatus as a public servant. Therefore, the position of the government apparatus in public services is very strategic because it will greatly determine the extent to which the 
Hetty Evarina Situmorang et.al. Implementation of standard operational procedure (SOP) for services, government policy and information technology of communication on improving public satisfaction of Balai Karantina Pertanian Kelas II Medan.

government is able to provide the best possible service to the community, which in this way will determine the extent to which the state has carried out its role properly in accordance with the objectives of its establishment.

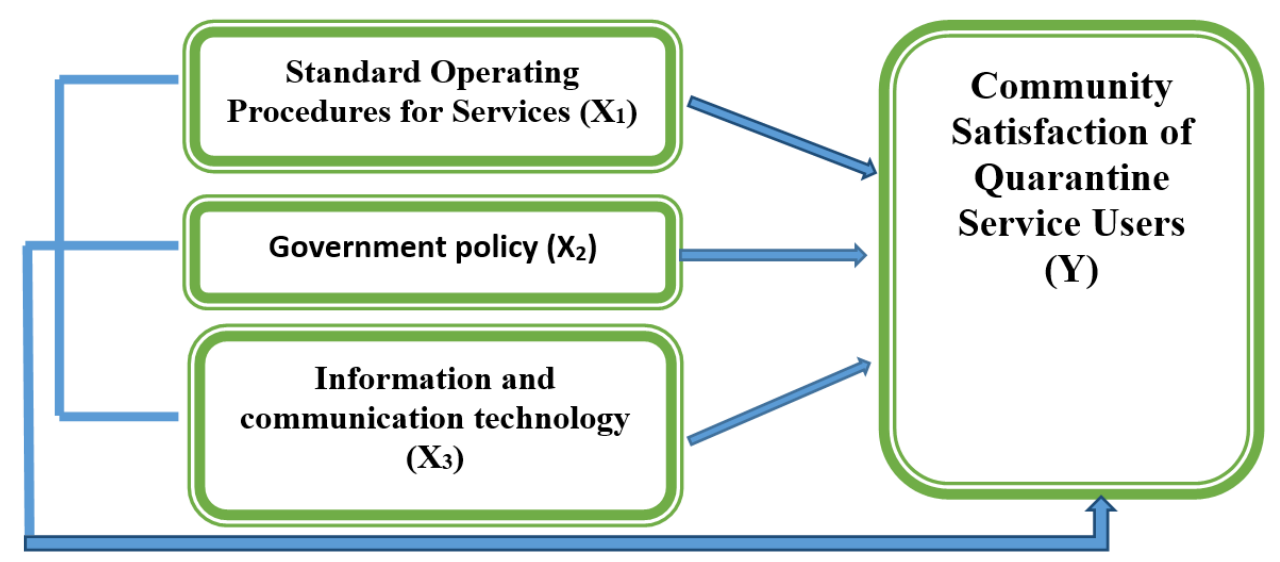

Figure 1. Conceptual Framework

\section{Hypotheses}

Ha1 : There is a positive and significant influence between the Standard Operating Procedures (SOP) of Services on Increasing Community Satisfaction at the Kantor Balai Karantina Pertanian Kelas II Medan

$\mathrm{Ha} 2$ : There is a positive and significant influence between government policies on increasing community satisfaction at the Kantor Balai Karantina Pertanian Kelas II Medan

Ha3 : There is a positive and significant influence between Information and Communication Technology on Increasing Community Satisfaction at the Kantor Balai Karantina Pertanian Kelas II Medan

Ha4 : Standard Operating Procedures (SOP) for Services, Government Policies and Information Communication Technology together have a positive and significant impact on increasing community satisfaction at the Kantor Balai Karantina Pertanian Kelas II Medan.

\section{RESEARCH METHOD}

In this study, the researcher used associative research. Associative research is research on the relationship of two or more variables which can also be called a causal relationship in which in this study there is an independent variable (cause) namely the influencing variable and the dependent variable (effect) namely the affected variable (Sinulingga, 2011). These two things make it easier for the author to obtain objective data in order to know and understand the effect of the application of standard operating procedures (SOPs) for services, government policies and the use of information and communication technology to increase community satisfaction at the Kantor Balai Karantina Pertanian Kelas II Medan. The research was conducted for three months, namely in November 2020 January 2021.

The population used in this study were service users at the Kantor Balai Karantina Pertanian Kelas II Medan with a total of 80 people. Service User is a term for an individual or a business entity that requires quarantine services. In this study, the authors narrow the population, namely the number of people who use quarantine services who have used quarantine services repeatedly as many as 80 respondents who are divided into users of animal quarantine services and users of plant quarantine services according to the services received. Researchers used all populations as samples, as many as 80 respondents. 
Hetty Evarina Situmorang et.al. Implementation of standard operational procedure (SOP) for services, government policy and information technology of communication on improving public satisfaction of Balai Karantina Pertanian Kelas II Medan.

\section{RESULT AND DISCUSSION \\ R-Square test Results}

\begin{tabular}{|c|c|c|c|c|}
\hline \multicolumn{5}{|c|}{$\begin{array}{r}\text { Table 1: R Suquare } \\
\text { Model Summary }\end{array}$} \\
\hline Model & $\mathbf{R}$ & R Square & $\begin{array}{l}\text { Adjusted R } \\
\text { Square }\end{array}$ & $\begin{array}{l}\text { Std. Error of the } \\
\text { Estimate }\end{array}$ \\
\hline 1 & $.812^{\mathrm{a}}$ & .659 & .645 & 1.43016 \\
\hline \multicolumn{5}{|c|}{$\begin{array}{l}\text { a. Predictors: (Constant), Information and Communication Technology, Government Policy, Standard } \\
\text { Operating Procedure } \\
\text { b. Dependent Variable: Community Satisfaction }\end{array}$} \\
\hline
\end{tabular}

The adjusted $r$-square value $=0.645$, this means that the magnitude of the influence of the independent variable on the dependent variable Y (community satisfaction) is $0.645 \times 100 \%=64.5 \%$. In other words, $64.5 \%$ of the variables of community satisfaction can be explained by the variables of Standard Operating Procedures (SOP), Government Policy, Information and Communication Technology and Community Satisfaction, while the rest $(35.5 \%)$ is explained by other factors not examined.

\section{Hypothesis Test Results - Simultaneous F Test Results}

The F-test was simultaneously carried out to determine whether the 3 independent variables X1 (Standard Operating Procedures (SOP) Services), X2 (Government Policy) and X3 (Information and Communication Technology) had a significant effect on the dependent variable Y (Community Satisfaction).

Table 2: Simultaneous F Test Results

\begin{tabular}{|c|c|c|c|c|c|c|}
\hline \multicolumn{7}{|c|}{ ANOVA $^{a}$} \\
\hline & Model & $\begin{array}{l}\text { Sum of } \\
\text { Squares }\end{array}$ & Df & Mean Square & $\bar{F}$ & Sig. \\
\hline \multirow{3}{*}{1} & Regression & 300.352 & 3 & 100.117 & 48.948 & $.000^{b}$ \\
\hline & Residual & 155.448 & 76 & 2.045 & & \\
\hline & Total & 455.800 & 79 & & & \\
\hline
\end{tabular}

Based on the data presented in table 2 , it can be concluded that the 3 variables $\mathrm{X} 1$ (Standard Operating Procedures (SOP) Services, X2 (Government Policy) and X3
(Information and Communication Technology) have a significant influence on the dependent variable Y (Community satisfaction).

\section{Partial T-Test Results}

Tabel 3. Partial T-Test Results

\begin{tabular}{|c|c|c|c|c|c|c|}
\hline \multicolumn{7}{|c|}{ Coefficients $^{a}$} \\
\hline & \multirow{2}{*}{ Model } & \multicolumn{2}{|c|}{$\begin{array}{l}\text { Unstandarized } \\
\text { Coefficients }\end{array}$} & \multirow{2}{*}{$\begin{array}{c}\begin{array}{c}\text { Standarized } \\
\text { Coefficients }\end{array} \\
\text { Beta } \\
\end{array}$} & \multirow[t]{2}{*}{$\mathrm{t}$} & \multirow{2}{*}{ Sig. } \\
\hline & & B & Std. Error & & & \\
\hline \multirow{4}{*}{1} & (Constant) & 1.039 & 3.917 & & .265 & .792 \\
\hline & Standard Operating Procedure & .495 & .063 & .575 & 7.850 & .000 \\
\hline & Government policy & .274 & .071 & .283 & 3.873 & .000 \\
\hline & $\begin{array}{l}\text { Information and communication } \\
\text { technology }\end{array}$ & .439 & .100 & .295 & 4.389 & .000 \\
\hline
\end{tabular}


Hetty Evarina Situmorang et.al. Implementation of standard operational procedure (SOP) for services, government policy and information technology of communication on improving public satisfaction of Balai Karantina Pertanian Kelas II Medan.

\section{The Effect of Standard Operating Procedures (SOP) on Community Satisfaction}

Table 3 shows that the t-count value of X1 (Standard Operating Procedures (SOP) for Services) $=7,850$ with a significance (p-value) of 0.000 . When compared with the value of t-table $=1.99$ (for $\mathrm{N}=80$ or $\mathrm{df}=76$ ) and sig- $\alpha=0.05$, it can be seen that t-count X1 (7.850) > t-table (1.99) and p-value (0.000) < 0.05, concluded that the variable X1 (Standard Operating Procedures (SOP) Services) has a significant effect on the dependent variable Y (community satisfaction). This means that the better the Standard Operating Procedure (SOP), the higher the community's satisfaction with the services of the Kantor Balai Karantina Pertanian Kelas II Medan.

\section{The Effect of Government Policy on Community Satisfaction}

The results of the analysis show that government policies have a significant influence on people's satisfaction. This is indicated by the t-count X2 (3.873) $>$ t-table (1.99) and p-value (0.002) <0.05. This means that the better the government's policies, the higher the community's satisfaction with the services of the Kantor Balai Karantina Pertanian Kelas II Medan.

\section{The Effect of Information and Communication Technology on Public Satisfaction}

The results of the analysis show that Information and Communication Technology has a significant influence on people's satisfaction. This is indicated by the value of t-count X3 (4.389) > t-table (1.99) and p-value $(0.016)<0.05$. This means that the higher the information and communication technology, the higher the community's satisfaction with the services of the Kantor Balai Karantina Pertanian Kelas II Medan.

\section{CONCLUSION}

$\begin{array}{cl}\text { Partially, } & \text { Standard Operating } \\ \text { Procedures (SOP) } & \text { have a positive and }\end{array}$

significant effect on the satisfaction of the community using quarantine services at the Kantor Balai Karantina Pertanian Kelas II Medan and is the variable that has the highest influence compared to the variables of Government Policy and Information and Communication Technology at the Kantor Balai Karantina Pertanian Kelas II Medan.

Government policies partially have a positive and significant effect on the satisfaction of people using quarantine services at the the Kantor Balai Karantina Pertanian Kelas II Medan.

Information and Communication Technology partially has a positive and significant impact on community satisfaction using the Kantor Balai Karantina Pertanian Kelas II Medan

Simultaneously Standard Operating Procedures (SOP) Services, Government Policies and Information Communication Technology have a significant effect on the Satisfaction of the Quarantine Service User Community at the the Kantor Balai Karantina Pertanian Kelas II Medan which is shown in the $\mathrm{F}$ test with a significant figure of $48.95 \%$ while the remaining $51.05 \%$ is explained by other variables or factors not examined.

Based on the results of the Partial test with the $\mathrm{T}$ test, it can be seen that the variable that has the least effect on the satisfaction of the service user community at the Kantor Balai Karantina Pertanian Kelas II Medan is the Government Policy variable, therefore the Kantor Balai Karantina Pertanian Kelas II Medan needs to further increase socialization to the public about every policy issued by the government.

\section{Acknowledgement: None \\ Conflict of Interest: None \\ Source of Funding: None}

\section{REFERENCES}

1. Yoeti, H. (2005). Customer Service Cara Efektif Memuaskan Pelanggan. Jakarta: PT. Pradnya Paramita.

2. Asmani, Jamal (2011). Tips Efektif Pemanfaatan Teknologi Informasi dan 
Hetty Evarina Situmorang et.al. Implementation of standard operational procedure (SOP) for services, government policy and information technology of communication on improving public satisfaction of Balai Karantina Pertanian Kelas II Medan.

Komunikasi dalam Dunia Pendidikan. Yogyakarta: Diva Press

3. Achmad et.al.2012, Layanan Cinta (Perwujudan Layanan Prima Perpustakaan). CV. Sugeng Seto, Anggota IKAPI, Jakarta

4. Arikunto, S. (2010). Prosedur Penelitian Suatu Pendekatan Praktek. Jakarta: Asdi Mahasatya.

5. Atmoko, T. (2011). Standar Operasional Prosedur (SOP) dan Akuntabilitas Kinerja Instansi Pemerintah. Bandung.

6. Damopoli, R. V. (2014). Implementasi Kebijakan Pemerintah Daerah dalam Pelayanan Kesehatan Masyarakat. 23-36.

7. Dharma, R. (2013). Analisis Pengaruh Harga, Pelayanan dan Fasilitas Pendukung terhadap Kepuasan Pelanggan pada PT. Semen Tonasa Kabupaten Pangkep. Jurnal Fakultas Ekonomi Universitas Hasanuddin Makassar,

8. Dwiyanto, A. (2015). Manajemen Pelayanan Publik : Peduli, Inklusif, dan Kolaborasi. Yogyakarta: Gadjah Mada University Press.

9. Fahlefi, Z. (2015). Penerapan Teknologi Informasi bagi Pelaksanaan Pelayanan Publik (Studi Kasus pada BP2TSP Kota Samarinda). Jurnal Paradigma Universitas Mulawarman, 155-166.

10. Fauziannur, M. (2018). Pengaruh Kualitas Pelayanan terhadap Kepuasan Nasabah pada Bank BPD Kaltim Syariah Cabang Samarinda. Fakultas Ekonomi dan Bisnis Universitas Mulawarman, 1-18.

11. Febryan, D., \& Tedi, E. (2016). Implementasi Pelayanan Publik Berbasis Teknologi Informasi (Studi Kasus di Badan Pelayanan Perizinan Terpadu dan Penanaman Modal Kota Bogor). Jurnal Adiministrasi Negara Fakultas Ilmu Sosial dan Ilmu Politik Universitas Udayana, 1-9.

12. Gerson, R. F. (2014). Mengukur Kepuasan Pelanggan, terj. Jakarta: Lembaga Manajemen PPM.

13. Ghozali, I. (2012). Aplikasi Analisis Multivariate dengan Program IBM SPSS. Yogyakarta: Universitas Diponegoro.

14. Haryono, P. (2018). How To Manage Customer Voice. Yogyakarta: Andi Offset.
15. Hayat. (2017). Manajemen Pelayanan Publik. Jakarta: PT. Raja Grafindo Persada.

16. Insani, I. (2010). Pengembangan Kapasitas Sumber Daya Manusia Daerah dalam Rangka Peningkatan Tranparansi dan Akuntabiltas Pengelolaan Keuangan Daerah.

17. Kotler, P., \& Amstrong, G. (2012). Prinsip - Prinsip Pemasaran. Jakarta: Erlangga.

18. Laksmi, F., \& Budiantoro. (2008). Manajemen Perkantoran Modern. Jakarta: Pernaka.

19. Laudon, K. C., \& Laudon, J. P. (2018). Sistem Informasi Manajemen Mengelola Perusahaan Digital - terjemahan. Jakarta: Salemba Empat.

20. Mahmudi (2015). Manajemen Kinerja Sektor Publik Edisi Kedua. Yogyakarta: UPP STIM YKPN.

21. Mulyadi (2014). Sistem Akuntansi. Yogyakarta: Bagian Penerbitan Sekolah Tinggi Ilmu Ekonomi YKPN

22. Nugroho, Adi (2010). Rekayasa Perangkat Lunak menggunakan UML \& Java. Yogyakarta: Andi Offset.

23. Osborne, D., \& Plastrik, P. (2010). Banishing Bureaucracy, The Five Strategies for Reiventing Government, terjemahan Memangkas Birokrasi : Lima Strategi Menuju Pemerintahan Wirausaha. Jakarta: PPM.

24. Paongganan, H. W. (2014). Pengaruh Teknologi Informasi terhadap Kualitas Layanan Pemustaka pada Badan Perpustakaan dan Arsip Daerah Provinsi Sulawesi Tenggara. Jupiter, 11-21.

25. Pasolong, M. D. (2016). Metode Penelitian Administrasi Publik. Bandung: Alfabeta.

26. Patton, D. P. (2008). Pelayanan Sepenuh Hari. Jakarta: PT. Pustaka Delapratasa.

27. Puji, Indah Hartatik (2014). Buku Pintar Membuat Standar Operasional Prosedur. Yogyakarta: Flashbook.

28. Purba (2019) Pengaruh Penerapan Standar Operasional Prosedur (Sop) Pelayanan Terhadap Kepuasan Masyarakat Pada Dinas Kependudukan Dan Catatan Sipil Kabupaten Tapanuli Utara, Jurnal edisi Agustus 2019 
Hetty Evarina Situmorang et.al. Implementation of standard operational procedure (SOP) for services, government policy and information technology of communication on improving public satisfaction of Balai Karantina Pertanian Kelas II Medan.

29. Putria, N. E. (2013). Pengaruh Implementasi Teknologi Informasi dan Kualitas Pelayanan Jasa terhadap Kepuasan Pelanggan pada PT. PLN Batam. CBIS Journal, 77-96.

30. Rahadi, D. R. (2007). Peranan Teknologi Informasi dalam Peningkatan Pelayanan di Sektor Publik. Seminar Nasional Teknologi 2007 (SNT 2007).

31. Rahayu, S., \& Sihombing, M. (2018). Hubungan Implementasi Sistem Operasional Prosedur berdasarkan Permenpan Nomor 35 Tahun 2012 terhadap Kepuasan Pelanggan di BKN Regional VI Medan. Jurnal Administrasi Publik, 72-90.

32. Ramadani, T. (2019). Implemantasi Kebijakan Pengelolaan Komunikasi Publik di Kementerian Energi dan Sumber Daya Mineral. Borneo Administrator, 118.

33. Rangkuti, F. (2006). Bisnis Plan Teknik Membuat Perencanaan Bisnis dan Analisis Kasus. Jakarta: PT. Gramedia Pustaka Utama.

34. Ratna, E. M. (2018). Pengaruh Fasilitas Kantor, Kualitas Pelayanan dan Standar Operasional Prosedur terhadap Tingkat Kepuasan Pengunjung pada Dinas Perpustakaan dan Kearsipan Daerah Kabupaten Batanghari. EKSIS : Jurnal Ilmiah Ekonomi dan Bisnis, 1-6.

35. Roth, A., Givi, C., \& Seal, G. (n.d.). Operating Strategies for the 1990s: elements comprising word-class manufacturing.

36. Rusman (2011). Pembelajaran Berbasis Teknologi Informasi dan Komunikasi : Mengembangkan Profesionalisme Guru. Jakarta: Rajawali Pers PT. Raja Grafindo Persada.

37. Saleh, A. M. (2010). Public Service Communication. Malang: UMM Press.

38. Sawyer, W. (2009). Using Information Technology Pengenalan Praktis Dunia Komputer dan Komunikasi. Jakarta: Andi.

39. Semil, N. (2018). Pelayanan Prima Instansi Pemerintah. Depok: Prenadamedia Group.

40. Semil, N. S. (2018). Pelayanan Prima Instansi Pemerintah. Depok: Prenadamedia Group.
41. Sirajuddin, I. A. (2014). Implementasi Kebijakan Pemerintah Daerah dalam Pelayanan Publik Dasar Bidang Sosial di Kota Makassar. Jurnal Administrasi Publik, 1-14.

42. Sinulingga, S. (2011). Metode Penelitian. Medan: USU Press.

43. Soekanto, S. (2015). Sosiologi : Suatu Pengantar. Jakarta: Raja Grafindo Persada.

44. Subarsono, AG. (2013). Analisis Kebijakan Publik : Konsep, Teori dan Praktik. Yogyakarta: Pustaka Pelajar.

45. Sugiyono. (2011). Metode Penelitian Kuantitatif, Kualitatif dan $R \& D$. Bandung: Afabeta.

46. Suharno. (2010). Dasar - Dasar Kebijakan Publik. Yogyakarta: UNY Press.

47. Suharto, Edi. (2012). Analisis Kebijakan Publik. Bandung: Alfabeta.

48. Supranto, J., \& Limakrisna, N. (2010). Pemasaran untuk Pimpinan Sektor Publik dan Organisasi Nirlaba yang Visioner. Jakarta: Salemba Empat.

49. Supriatna (2013). Konsep Dasar Desain Pembelajaran. Jakarta: Pusat Pengembangan dan Pemberdayaan Pendidik dan Tenaga Kependidikan.

50. Sutabri, Tata (2014). Pengantar Teknologi Informasi. Yogyakarta: Andi.

51. Sutarman. (2010). Pengantar Teknologi Informasi. Jakarta: Bumi Aksara.;

52. Tambunan, R. M. (2013). Pedoman Penyusunan Standar Operating Procedures (SOP). Jakarta: Maistas Publishing.

53. Tambunan, T. S. (2019). Standar Operasional Prosedur Instansi Pemerintah. Bandung: Yrama Widya.

54. Tanjung, Y. O. (2017). Pengaruh Penerapan Standar Operasional Prosedur terhadap Kepuasan Pelayanan di Pelabuhan Perikanan Nusantara Sibolga Provinsi Sumatera Utara. akultas Perikanan dan Kelautan Universitas Riau Pekanbaru, 1-15.

55. Tefa, G. (2016). Penerapan Kebijakan Pemerintah Daerah terhadap Pelayanan Pembuatan Kartu Keluarga (Studi Kasus pada Dinas Kependudukan dan Pencatatan Sipil Kabupaten Tulungagung Provinsi 
Hetty Evarina Situmorang et.al. Implementation of standard operational procedure (SOP) for services, government policy and information technology of communication on improving public satisfaction of Balai Karantina Pertanian Kelas II Medan.

Jawa Timur). Jurnal Politikologi Institut Pemerintahan dalam Negeri, 67-79.

56. Tjiptono, F., \& Chandra, G. (2012). Pemasaran Strategik. Yogyakarta: Andi.

57. V.Sujarweni, \& P.Endrayanto. (2012). Statistika untuk Penelitian. Yogyakarta: Graha Ilmu.

58. Wibisono, P. (2016). Mengelola Kinerja Kementerian dan Pemerintahan. Yogyakarta: BPFE-Yogyakarta.

59. Wulan, R. R., \& Mustam, M. (2014). Peningkatan Kualitas Pelayanan Publik dalam Rangka Reformasi Birokrasi di Kantor Pertanahan Kota Semarang. Fakultas Ilmu Sosial dan Politik Universitas Diponegoro, 30-41.

60. Wulan, R. R., \& Mustam, M. (2016). Peningkatan Kualitas Pelayanan Publik dalam Rangka Reformasi Birokrasi di
Kantor Pertanahan Kota Semarang. Fakultas Ilmu Sosial Ilmu Politik Universitas Diponegoro, 1-20.

61. Zeethari, V., \& Patasuraman. (2010). Delivering Quality Service - Balancing Customer, Perception and Expectation. USA: The Free Press.

How to cite this article: Hetty Evarina Situmorang, Endang Sulistya Rini, Sugiharto Pujangkoro. Implementation of standard operational procedure (SOP) for services, government policy and information technology of communication on improving public satisfaction of Balai Karantina Pertanian Kelas II Medan. International Journal of Research and Review. 2022; 9(1): 461-469. DOI: https://doi.org/10.52403/ijrr. 20220152 